\title{
Autoimmune Encephalitis in Critical Care: Optimizing Immunosuppression
}

\author{
Daniel B. Rubin, MD, $\mathrm{PhD}^{1,2}$ Ayush Batra, $\mathrm{MD}^{3}$ \\ ${ }^{1}$ Department of Neurology, Massachusetts General Hospital, Harvard \\ Medical School, Boston, Massachusetts \\ 2 Department of Neurology, Brigham and Women's Hospital, Harvard \\ Medical School, Boston, Massachusetts \\ ${ }^{3}$ Ken \& Ruth Davee Department of Neurology, Northwestern \\ Memorial Hospital, Northwestern University Feinberg School of \\ Medicine, Chicago, Illinois
}

Semin Respir Crit Care Med 2017;38:807-820.

\author{
Address for correspondence Henrikas Vaitkevicius, MD, Department \\ of Neurology, Brigham and Women's Hospital, Harvard Medical \\ School, 60 Fenwood Road, Boston, MA 02115 \\ (e-mail: hvaitkevicius@partners.org).
}

\begin{abstract}
Keywords

- autoimmune neurology

- paraneoplastic disorder

- limbic encephalitis

- neurologic disorder

Autoimmune diseases affecting the nervous systems are a common cause of admission to the intensive care unit (ICU). Although there exist several well-described clinical syndromes, patients more commonly present with progressive neurologic dysfunction and laboratory and radiographic evidence of central nervous system (CNS) inflammation. In the critical care setting, the urgency to intervene to prevent permanent damage to the nervous system and secondary injury from the systemic manifestations of these syndromes often conflicts with diagnostic uncertainty. Furthermore, treatment is limited by current therapeutic agents that remain non-specific for individual diseases, especially for those whose pathophysiology remains unclear. Primary autoimmune, paraneoplastic, parainfectious, and iatrogenic neurologic disorders all share the common underlying pathophysiology of an adaptive immune response directed against an antigen within the nervous system. Several different mechanisms of immune dysfunction are responsible for pathogenesis within each of these categories of disease, and it is at this level of pathophysiology that the most effective and appropriate therapeutic decisions are made. In this review, we outline the basic diagnostic and therapeutic principles in the management of autoimmune diseases of the nervous system in the ICU. We approach these disorders not as lists of distinct clinical syndromes or molecular targets of autoimmunity but rather as clusters of syndromes based on these common underlying mechanisms of immune dysfunction. This approach emphasizes early intervention over precise diagnosis. As our understanding of the immune system continues to grow, this framework will allow for a more sophisticated approach to the management of patients with these complex, often devastating but frequently reversible, neurologic illnesses.
\end{abstract}

Autoimmune and noninfectious inflammatory disorders of the central and peripheral nervous systems encompass a group of diseases increasingly encountered in the intensive care unit (ICU). ${ }^{1}$ Traditionally, these disorders are reviewed as a list of diseases with corresponding diagnostic guidelines and treatment options. However, this approach is less relevant in fulminant disorders presenting to an ICU, when a comprehensive diagnostic workup cannot feasibly be completed prior to the need for intervention to prevent further neurologic injury. Additionally, despite having the clinical,
Issue Theme Advancements in Neurocritical Care and Emergency Neurology; Guest Editors: David Y. Hwang, MD, FNCS, and David M. Greer, MD, MA, FCCM, FAHA, FNCS, FAAN, FANA Publishers, Inc., 333 Seventh Avenue, New York, NY 10001, USA. Tel: +1(212) 584-4662.
DOI https://doi.org/ 10.1055/s-0037-1608771. ISSN 1069-3424. 
laboratory, and radiographic markers of autoimmunity, some patients elude formal diagnosis.

In recent years, research into the basic immunological processes underlying many of these syndromes has revealed several common pathophysiologic mechanisms. At the most basic level, all autoimmune disorders of the nervous system are caused by an adaptive immune response directed against an antigen within the nervous system. Several overlapping categories of autoimmune neurological disease-including primary autoimmune, paraneoplastic, and parainfectiousare mediated by the abnormal adaptive immune response. The pathologic response is induced by either autoantigens (self-antigens) or foreign antigens. Autoantigens recruit the adaptive immune system in autoimmune and paraneoplastic disorders. In paraneoplastic disorders, which occur in the context of a neoplasm, the immune response is directed against neuronal antigens that are ectopically expressed by the tumor (e.g., limbic encephalitis caused by the expression of the ANNA-1 ( $\mathrm{Hu}$ ) antigen by small cell lung cancer). ${ }^{2}$ Parainfectious conditions are mediated by an abnormal or enhanced immune response triggered by a foreign antigen (e. g., Guillain-Barré syndrome caused by molecular mimicry resulting in the production of antiganglioside antibodies). ${ }^{3}$ Some conditions, such as anti-NMDA receptor encephalitis, can be autoimmune (without an associated neoplasm), paraneoplastic (related to ovarian teratoma), ${ }^{4}$ or parainfectious (as in post-HSV anti-NMDA receptor encephalitis). ${ }^{5}$ Although the source of the inciting antigen may vary, the underlying mechanism of immune dysfunction is likely the same in each of these settings. Iatrogenic autoimmune neurologic disorders are now garnering increased recognition, given the rise in the incidence of these disorders as a result of powerful immune-activating therapies for oncologic indications. ${ }^{6}$ With the increasing use of immune checkpoint inhibitors and chimeric antigen receptor (CAR) T cells for the treatment of cancer, the incidence of these disorders is likely to continue to rise in coming years.

As such, many of these disorders are better classified not by the specific autoantigen involved but rather by their common underlying pathogenic mechanisms of immune dysfunction. This is important because the presence of certain autoantibodies, such as anti-GAD65 or anti-ANNA$1 \mathrm{Hu})$, can often be observed in several different autoimmune neurologic syndromes ${ }^{3,7}$ and in certain cases may simply be a marker for an autoimmune process with an unknown pathologic target (e.g., anti-thyroid peroxidase [TPO] in Hashimoto's encephalopathy ${ }^{8,9}$ ). Additionally, as described earlier, more than one pathogenic mechanism can give rise to the same clinical syndrome. ${ }^{3}$ As an example, limbic encephalitis can be caused by autoantibodies against NMDA receptor and T-cell-mediated cytotoxicity associated with anti-ANNA1 (Hu) antibodies. Ultimately, though, the key to this classification scheme, based on mechanism of underlying immune dysfunction, is that it emphasizes early disease-modifying treatment above definitive diagnosis. Furthermore, clinical syndromes that elude formal diagnosis can at the very least be characterized immunologically to guide a rational approach to empiric therapy in the ICU.
Immune mechanisms and related pathology that are implicated in autoimmune disorders of the nervous system can be classified into disorders of T-cell-mediated pathology, autoantibody-mediated pathology, granulomatous inflammation, autoinflammatory pathology, and iatrogenic activation of a specific immune process or target ( $\mathbf{- T a b l e ~} \mathbf{1}$ ).

\section{latrogenic Autoimmunity}

Iatrogenic autoimmunity is not a novel concept. Drug-induced lupus is a well-established adverse effect of several nonimmunomodulatory drugs, including procainamide, hydralazine, and minocycline. The incidence of iatrogenic autoimmunity has risen with the introduction of immunomodulatory therapeutics, including interferon- $\alpha$, tumor necrosis factor- $\alpha$ (TNF $\alpha$ ) inhibitors and, most recently, checkpoint inhibitors and genetically altered CAR-T cells. ${ }^{6}$ Despite the risk of development of systemic and CNS autoimmune disorders, the use of immunomodulatory therapies has become the standard of care in patients with autoimmune disorders and for many oncologic indications, such as advanced melanoma. Thus, understanding and early recognition of their CNS-related adverse effects will be imperative. For example, interferon- $\alpha$ has been linked to the exacerbation of psoriasis and sarcoidosis ${ }^{10}$ and the development of autoimmunity manifesting as vasculitis, inflammatory arthritis, and drug-induced lupus, among others. TNF $\alpha$ inhibitors, which are typically used for the management of rheumatoid arthritis and inflammatory bowel disease, carry an increased risk for CNS and peripheral nervous system demyelination $^{11,12}$ and drug-induced lupus. ${ }^{13,14}$

Immune checkpoint inhibitors are a novel class of therapeutics designed to target the inhibitory pathways in the immune system that maintain self-tolerance and modulate the immune response. $^{15}$ Cytotoxic T-lymphocyte-associated antigen 4 (CTLA-4) was the first clinically targeted immune checkpoint receptor and functions by regulating the central expansion of $\mathrm{T}$ cells. The interaction of T-cell-expressed CTLA- 4 with CD80 or CD86 on antigen-presenting cells blocks T-cell costimulation and abrogates an activated T-cell response. Inhibition of CTLA-4 thus overcomes a block in costimulatory signals that are required for activation of both naive $\mathrm{T}$ cells and resting clones, harnessing the host's native immune response against cancer. ${ }^{15,16}$ Another clinically relevant immune checkpoint receptor, programmed cell death protein 1 (PD-1), and its ligand (PDL1) have been targeted to prevent the inhibition of cytotoxic T cells via upregulated ligands PD-L1 and PD-L2 in the tumor microenvironment. ${ }^{15}$ The checkpoint inhibitors ipilimumab (human antibody to CTLA-4) and pembrolizumab and nivolumab (PD-1 antagonists) and combination strategies with immunotherapy have offered cancer patients durable disease control. However, they have also unmasked unique neurological toxicities that can range from minor headaches and confusional states to severe disabling demyelinating disorders and immune-mediated encephalitis. ${ }^{17}$ The incidence of immunerelated neurological adverse events with the use of checkpoint inhibitors is reported to be as high as $1 \%{ }^{18}$ Checkpoint inhibitors may trigger the immune response against the pituitary gland ${ }^{19}$ and specific neuronal antigens, leading to autoimmune 

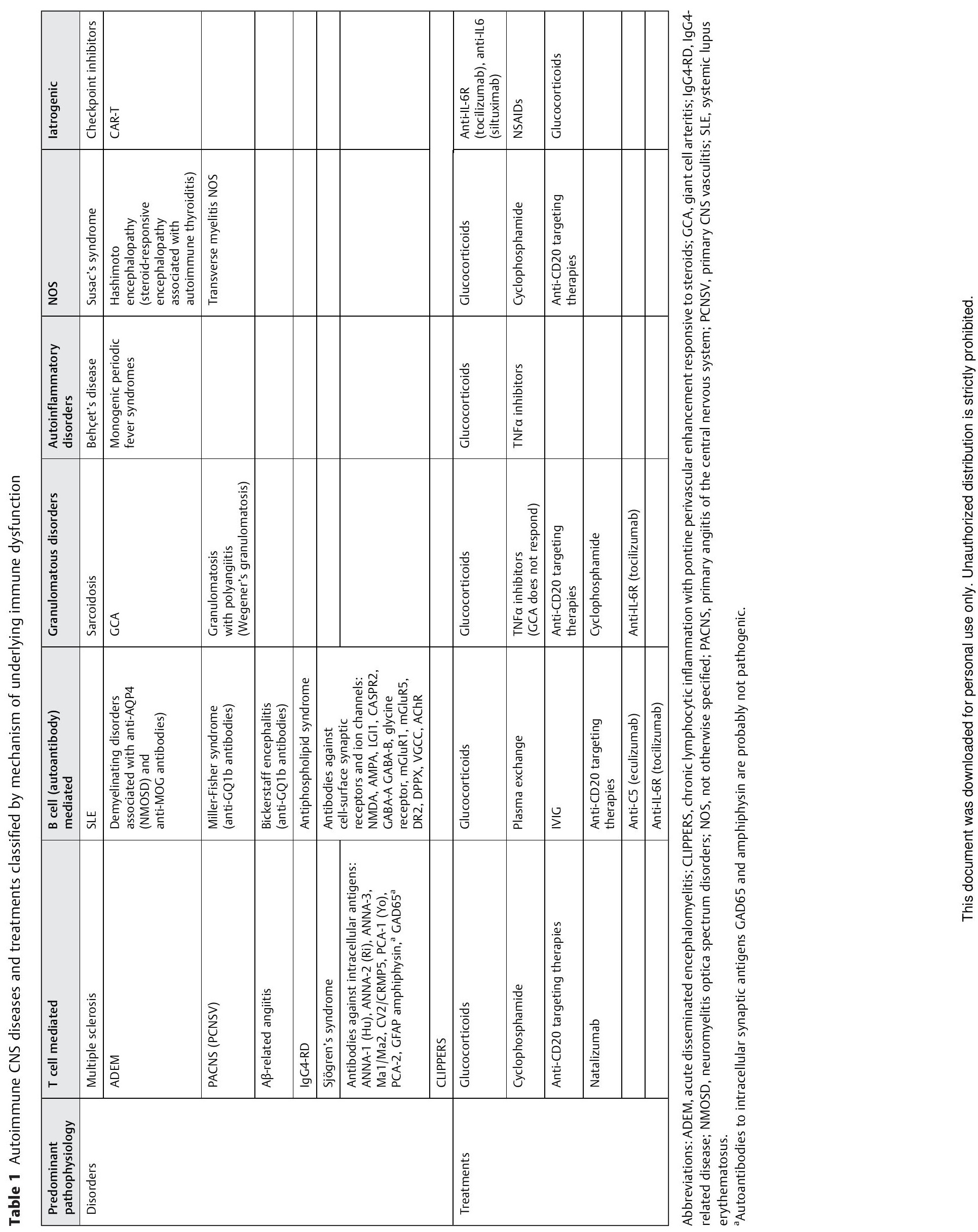
Table 2 CNS disorders associated with immune-mediated treatments

\begin{tabular}{|c|c|c|}
\hline $\begin{array}{l}\text { Treatment } \\
\text { class }\end{array}$ & Medication & Clinical syndrome \\
\hline Anti-TNF $\alpha$ & $\begin{array}{l}\text { Adalimumab } \\
\text { Etanercept } \\
\text { Infliximab }\end{array}$ & $\begin{array}{l}\text { Demyelinating disorders }{ }^{13} \\
\text { (CNS, including optic } \\
\text { neuritis, }{ }^{75} \text { PNS) }\end{array}$ \\
\hline Anti-IL-6R & Tocilizumab & $\begin{array}{l}\text { Demyelinating disorders, } \\
\text { multiple sclerosis } \\
{ }^{76} \\
\text { Cognitive impairment } \\
\text { with leukoencephalopathy }\end{array}$ \\
\hline Anti-PD1/L1 & $\begin{array}{l}\text { Nivolumab } \\
\text { Pembrolizumab }\end{array}$ & $\begin{array}{l}\text { Myasthenia gravis } \\
\text { Encephalitis }^{17} \\
\text { Demyelinating disorders } \\
\text { PRES } \\
\text { Stiff-person syndrome } \\
79\end{array}$ \\
\hline Ant CTLA-4 & $\begin{array}{l}\text { Abatacept } \\
\text { Belatacept } \\
\text { Ipilimumab }\end{array}$ & $\begin{array}{l}\text { Hypophysitis }{ }^{18} \\
\text { Ischemic stroke }^{78} \\
\text { PRES }^{78} \\
\text { Myasthenia gravis } \\
\text { Guillain-Barré syndrome }\end{array}$ \\
\hline
\end{tabular}

Abbreviations: CNS, central nervous system; PNS, peripheral nervous system; PRES, posterior reversible leukoencephalopathy syndrome.

encephalitis, ${ }^{20}$ even associated with anti-NMDA receptor antibodies reported in a single case. ${ }^{21}$ Ongoing development and use of checkpoint inhibitors will necessitate clinicians to become even more vigilant in their evaluation of adverse neurologic events and assessing for induced autoimmunity, especially given the broad spectrum of possible clinical syndromes (-Table 2).

CAR-T cells are genetically modified $\mathrm{T}$ cells that have a fabricated antigen receptor from multiple sources engineered to a specific target cell antigen. A patient's own cells are isolated, genetically modified, cloned, and reinfused to redirect T-cell specificity to a specific tumor-associated antigen. ${ }^{22}$ New generations of CAR-T cells have incorporated a costimulatory domain that offer a potentially durable treatment response but leave patients susceptible to potential side effects for years following therapy. Cytokine release syndrome (CRS) is the most common side effect encountered with CAR-T-cell therapy, and results from T-cell activation, proliferation, and production of endogenous cytokines. ${ }^{23}$ Symptoms can span fever and flu-like syndromes to systemic shock and multiorgan failure including profound neurotoxicity. These neurologic symptoms may range from headache and confusion to frank delirium, aphasia, seizures, and, in severe cases, coma. ${ }^{23,24}$ The mechanism for these immunemediated side effects are still being elucidated, but organ damage may occur by autoimmune mechanisms when CAR-T cells cross-react with native host antigens. ${ }^{25,26}$ Early recognition of side effects from CAR-T-cell therapy is essential. A grading scale for severity of CRS ranging from 1 to 5 has been employed to ensure adequate monitoring, with 1 and 2 representing symptoms that are non-life-threatening and 3 and 4 representing life-threatening symptoms usually requiring ICU level care. ${ }^{23}$

\section{T-Cell-Mediated Autoimmunity}

It should be noted that not all autoantibodies associated with neuroinflammatory conditions have a direct pathogenic role. Autoantibodies against intracellular cytoplasmic antigens, such as ANNA-1 (Hu), ANNA-2 (Ri), CV2/CRMP5, PCA-1 (Yo), and GFAP, are biomarkers of disease that are probably $\mathrm{T}$ cell mediated ( - Table $\mathbf{1})^{3}{ }^{3}$ Effector T cells uniformly cause cell death, which implies that such T-cell-mediated damage is irreversible and response to treatment is unfavorable.

\section{Autoantibody-Mediated Autoimmunity}

Autoantibodies have a pathogenic role when targeting surface antigens, such as AQP4, MOG, NMDA receptor, AMPA receptor, LGI1, CASPR2, and acetylcholine receptor (AChR) (- Table 1). They cause cellular dysfunction or injury through several different mechanisms, including receptor agonist or antagonist effect, antigen (receptor) internalization, activation of the complement, and antibody-dependent cell-mediated cytotoxicity (ADCC). ${ }^{27,28}$ Receptor agonist and antagonist effect as well as receptor internalization is reversible and effects of rapidly instituted immunotherapy are commonly very favorable.

\section{Other Mechanisms of Autoimmunity and Neuroinflammation}

Granulomatous inflammation is a form of chronic inflammation defined by the presence of histiocytes (activated macrophages), which engage in interaction with $\mathrm{CD} 4+\mathrm{T}$ cells. The histiocytes may coalesce to form multinucleated giant cells. Examples of granulomatous diseases include sarcoidosis and giant cell arteritis (GCAs; - Table 1). Autoinflammatory disorders are driven by dysregulated innate rather than adaptive immunity. ${ }^{29}$ In certain conditions, the mechanism of autoimmunity cannot be elucidated and is reported here as not otherwise specified (NOS). ${ }^{30}$

\section{Autoantigens in the Nervous System and Associated Disorders}

Antigens targeted by autoantibodies and $\mathrm{T}$ cells in primary neurologic autoimmune disorders are expressed by glia or neuronal cells. Examples of diseases characterized by glial autoimmunity include neuromyelitis optica spectrum disorders (NMOSD) mediated by antibodies to aquaporin-4 (AQP4), ${ }^{31}$ conditions mediated by antibodies to myelin oligodendrocyte glycoprotein (MOG), ${ }^{32}$ and a steroid-responsive meningoencephalomyelitis associated with antibodies to glial fibrillary acidic protein (GFAP). ${ }^{33}$ The spectrum of conditions associated with neuronal autoimmunity is much wider and depends on the cell types that are targeted, function of the targeted antigen, and immunopathogenic mechanisms that are recruited by $T$ cells or autoantibodies. ${ }^{3,34-36}$ Clinically recognizable autoimmune syndromes include limbic encephalitis, Bickerstaff brainstem encephalitis, Miller Fisher syndrome, neuromyelitis optica (NMO), subacute cerebellar degeneration, opsoclonus-myoclonus, stiffperson syndrome, Morvan syndrome, sensory neuronopathy 
Table 3 Well-characterized ("classic") autoimmune syndromes of the CNS

\begin{tabular}{|l|l|}
\hline Classic syndromes & Etiologies \\
\hline Limbic encephalitis & Paraneoplastic or primary autoimmune, HSV, HHV6, syphilis \\
\hline \multicolumn{1}{|c|}{$\begin{array}{l}\text { With faciobrachial dystonic seizures, hyponatremia } \\
\text { movement disorder (dyskinesias), dysautonomia }\end{array}$} & \multicolumn{1}{c|}{ Anti-LGl1 antibodies } \\
\hline Cerebellar ataxia (subacute cerebellar degeneration) & $\begin{array}{l}\text { Anti-NMDAR antibodies } \\
\text { Paraneoplastic [anti-PCA1 (Yo)], autoimmune (mGluR1, GAD65), } \\
\text { [ethanol, phenytoin, lithium, chemotherapy (cytarabine), } \\
\text { vitamin E deficiency], genetic [(spino)cerebellar ataxias] etiologies }\end{array}$ \\
\hline Opsoclonus-myoclonus(-ataxia) & Anti-ANNA-2 (Ri), anti-ANNA1 (Hu) antibodies \\
\hline Neuromyelitis optica & Anti-AQP4, anti-MOG antibodies \\
\hline Miller-Fisher syndrome & Anti-GQ1b antibodies \\
\hline Stiff-person syndrome & Anti-GAD65, anti-amphiphysin, anti-glycine receptor antibodies \\
\hline $\begin{array}{l}\text { Morvan syndrome (myokymia or neuromyotonia, } \\
\text { dysautonomia, sleep disturbance, } \\
\text { encephalopathy with visual hallucinations) }\end{array}$ & Anti-CASPR2 antibodies \\
\hline $\begin{array}{l}\text { Sensory ganglionopathy (neuronopathy) } \\
\text { Myasthenia gravis }\end{array}$ & $\begin{array}{l}\text { Paraneoplastic [anti-ANNA-1 (Hu) antibodies], Sjögren syndrome, } \\
\text { pyridoxine intoxication, platinum-based chemotherapy }\end{array}$ \\
\hline $\begin{array}{l}\text { Lambert-Eaton myasthenic syndrome } \\
\text { Anti-AChR, anti-MuSK antibodies }\end{array}$ \\
\hline
\end{tabular}

Abbreviations: CJD, Creutzfeldt-Jakob disease; EBV, Epstein-Barr virus; HHV6, human herpesvirus 6; HSV, herpes simplex virus; VZV, varicella zoster virus.

(ganglionopathy), myasthenia gravis (MG), and Lambert-Eaton myasthenic syndrome (-Table 3 ). The majority of the listed conditions have been associated with several autoantibodies. Conversely, the same antibody can cause different syndromes; for example, anti-ANNA-1 (Hu) antibody has been associated with limbic encephalitis and sensory ganglionopathy.

As our understanding of the basic pathologic mechanisms underlying autoimmunity continues to grow, it is very likely that this approach will become of increasing importance in the treatment of acute neuroinflammatory disorders. At present, this approach will hopefully be of help in guiding treatment decisions in these otherwise seemingly "datafree" zones of critical care medicine. For this reason, we will organize our discussion of these disorders on the pathophysiology of the underlying immune dysfunction, workup strategies, and available interventions. While there is an attempt to cluster these groups of disorders based on immunological processes involved, we do recognize that frequently multiple immunological pathways are implicated and multiple classes of interventions may be effective. Treatment strategies will focus on the spectrum of potential risk/benefit ratios for currently available immunologic therapies. Unfortunately, these disorders frequently remain untreated or undertreated because of difficulties with establishing the diagnosis, especially in cases when histopathological evaluation is essential. We suggest organizing these disorders based on the predominant pathophysiology of the underlying immune dysfunction, diagnostic strategies, and available interventions. This approach allows for the possibility of rapid interventions with empiric therapies in cases where diagnosis remains elusive.

\section{Epidemiology}

Autoimmune disorders of the nervous system are generally diagnosed at a younger age than other disorders of the nervous system warranting ICU level care, such as infectious or vascular injuries. However, all age groups can be equally affected. Certain disorders are well known to have a preponderance for a particular sex; NMO, multiple sclerosis (MS), Susac's syndrome, younger patients with MG, Sjögren's syndrome, ${ }^{37}$ Behçet's disease in the United States and northern Europe, ${ }^{31,38}$ and GCA are all more common in women than in men, whereas older patients with MG, chronic inflammatory demyelinating polyneuropathy, acute disseminated encephalomyelitis, ${ }^{39}$ Guillain-Barré syndrome, and IgG4-related disease (IgG4RD) ${ }^{40}$ are all slightly more common in men. No gender predilection exists in sarcoidosis or primary angiitis of the central nervous system (PACNS). ${ }^{41,42}$

\section{Diagnostic Strategy}

The differential diagnosis of new-onset neurologic dysfunction in the ICU is almost always first described generically as toxic/metabolic, infectious, neoplastic, primary vascular, or inflammatory (autoimmune/parainfectious/paraneoplastic). Autoimmune disorders are suspected when the disease course is subacute (progression over a course of $<3$ months); there is evidence of inflammation; and toxic, metabolic, hereditary disorders (e.g., mitochondrial diseases, inborn errors of metabolism), infectious, and primary neoplastic processes are less likely or have been excluded. ${ }^{7}$ The course of autoimmune neurologic disease may be monophasic, relapsing-remitting, 
or chronic progressive. Parainfectious disorders may present either acutely or subacutely, typically within weeks of the presentation of an inciting antigen (either an infectious disease or vaccination), and, unlike paraneoplastic and autoimmune conditions, more commonly have a monophasic course. Iatrogenic autoimmunity should be considered in patients undergoing therapy with immunomodulatory therapies such as immune checkpoint inhibitors or CAR-T cells.

Autoimmune disorders of the nervous system may be limited to (e.g., isolated neurosarcoidosis) and/or specific for the nervous system (e.g., MS) or may be a manifestation of a systemic disease (e.g., Sjögren syndrome). ${ }^{43}$ They can affect any neurological domain and frequently have multifocal presentations. Occasionally, well-defined clinical syndromes can be identified and these are extremely helpful; examples are listed in $\mathbf{- T a b l e ~} \mathbf{3}$. More frequently though, the clinical findings are nonspecific and additional evidence is sought through diagnostic testing.

All patients in the ICU should undergo a routine laboratory workup to rule out alternative, noninflammatory conditions, and to look for evidence of systemic medical conditions that may be associated with or underlying the presenting neurologic syndrome. ${ }^{37,43,44}$ For example, patients with neurosarcoidosis with hypothalamic involvement may have evidence of hormonal dysfunction, and a normocytic anemia may be seen as a consequence of chronic systemic inflammation in several different rheumatologic disorders. ${ }^{29}$ These medical conditions may also affect the treatment decisions. - Table 4 lists a set of basic screening laboratories that can be helpful to rule out alternative diagnoses or support the diagnosis of autoimmune dysfunction. There is an ongoing effort to establish immunologic biomarkers that could serve as an aid in the early identification of iatrogenic complications of immune checkpoint inhibitors and CAR-T cells.

One of the first diagnostic studies obtained in most cases is some form of neuroimaging. Although head computed tomography $(\mathrm{CT})$ is often the most rapidly attainable neuroimaging study, the diagnostic yield of this study in evaluating suspected neuroinflammatory disorders is very poor. CT angiography and postcontrast scans are somewhat more useful, particularly for cases of suspected CNS vasculitis. Magnetic resonance imaging of the brain (and often spine) with and without gadolinium has become the cornerstone of advanced neurological workup in the ICU. Patterns of T2/FLAIR abnormalities, restricted diffusion, contrast enhancement, and perfusion sequences may be specific for certain infectious, toxic, or inflammatory conditions (- Table 5). ${ }^{30,31,39,41,42,45,46}$ More advanced neuroimaging, including spectroscopy and fluorine-18-fluorodeoxyglucose $\left({ }^{18} \mathrm{~F}\right.$-FDG $)$ positron emission tomography/CT (FDG-PET/CT) of the brain, may also help establish a definitive diagnosis or to narrow down the differential diagnosis. Several studies in patients with paraneoplastic encephalitis have indicated PET-based glucose metabolism patterns that extend beyond limbic areas (e.g., frontotemporal hyper- and occipital hypometabolism in NMDAR encephalitis $\left.{ }^{47}\right) \cdot{ }^{48}$ Further studies are still needed to validate the positive and negative predictive value of abnormalities of glucose metabolism in FDG-PET/CT for the diagnosis of autoimmune
Table 4 Suggested clinical and laboratory tests in patients with suspected autoimmune disorders of the nervous system

\begin{tabular}{|c|c|}
\hline Alternative pathologies & $\begin{array}{l}\text { Markers of inflammation } \\
\text { and/or autoimmunity }\end{array}$ \\
\hline CBC w/diff ${ }^{a}$ & $\mathrm{ESR}^{\mathrm{a}}$ \\
\hline Electrolytes, glucose $\mathrm{a}^{\mathrm{a}}$ & $C R P^{a}$ \\
\hline $\mathrm{BUN} / \mathrm{Cr}^{\mathrm{a}}$ & $\mathrm{ANA}^{\mathrm{a}}$ \\
\hline $\mathrm{LFTs}^{\mathrm{a}}$ & Anti-dsDNA ${ }^{a}$ \\
\hline Ammonia & $\begin{array}{l}\text { Extractable nuclear antigens } \\
\text { (ENA)-anti-Ro/La }\end{array}$ \\
\hline Vitamin B12 & $\mathrm{ANCA}^{\mathrm{a}}$ \\
\hline Coagulation panel $^{\mathrm{a}}$ & $\begin{array}{l}\text { RF, ACPA (anti-citrullinated } \\
\text { peptide antibodies) }\end{array}$ \\
\hline Thyroid function & Antiphospholipid antibodies \\
\hline Cortisol & Myositis-specific antibodies \\
\hline Toxicology screen $^{a}$ & Complement levels \\
\hline Urinalysis and culture $^{\mathrm{a}}$ & Cryoglobulins \\
\hline Blood culture & IgG4 level \\
\hline Serologies for syphilis & Anti-TPO antibodies \\
\hline SPEP with immunofixation & ACE \\
\hline Serum-free light chains & HLA-B51 \\
\hline Serum flow cytometry & Anti-AQP4 antibodies \\
\hline$\beta 2$ microglobulin & Paraneoplastic antibodies \\
\hline
\end{tabular}

Abbreviations: ACE, angiotensin-converting enzyme; ANA, antinuclear antibody; ANCA, anti-neutrophil cytoplasmic antibody; BUN, blood urea nitrogen; CBC, complete blood cell count; $\mathrm{Cr}$, creatinine; CRP, C-reactive protein; ESR, erythrocyte sedimentation rate; LFTs, liver function tests; $\mathrm{RF}$, rheumatoid factor; SPEP, serum protein electrophoresis; TPO, thyroperoxidase; $w /$ diff, with differential.

${ }^{a}$ Basic laboratory evaluations.

encephalitis. ${ }^{49}$ - Table 6 describes additional imaging modalities and possible diagnostic conclusions to which these studies may lead.

An important test in the workup of inflammatory disorders of the nervous system is the lumbar puncture, and the diagnostic value of cerebrospinal fluid (CSF) analysis in CNS dysfunction cannot be emphasized enough. - Table 7 lists initial CSF studies that should be requested in all patients with suspected inflammatory neurologic disorders. CSF inflammation is most frequently defined by the presence of one or more of the following: pleocytosis ( $>5$ white blood cells), elevated protein $(>50 \mathrm{mg} / \mathrm{dL}$ ), the presence of oligoclonal bands (OCBs; $>1$ or higher dependent on local laboratory thresholds), and an elevated IgG index ( $>0.66)$. Hypoglycorrhachia (glucose $<45 \mathrm{mg} / \mathrm{dL}$ ) is typically seen in infectious (bacterial, fungal) and neoplastic conditions (leptomeningeal carcinomatosis), but can be observed in some inflammatory disorders (typically neurosarcoidosis, and also in PACNS and neuro-Behçet's disease). ${ }^{50}$ CSF cytology and flow cytometry may provide further insight into the pathogenesis of the underlying disease process, and can be helpful in identifying neoplastic or therapeutically induced etiologies..$^{510}$ 
Table 5 Magnetic resonance imaging findings and patterns of contrast enhancement

\begin{tabular}{|c|c|}
\hline Location and pattern & Possible etiologies \\
\hline $\begin{array}{l}\text { FLAIR hyperintensity in the } \\
\text { subarachnoid space }\end{array}$ & $\begin{array}{l}\text { Elevated CSF protein/cells-meningitis, carcinomatosis; artifact } \\
\text { (hyperoxygenation, propofol exposure, contrast extravasation) }\end{array}$ \\
\hline Mesiotemporal T2/FLAIR hyperintensities & $\begin{array}{l}\text { Limbic encephalitis of autoimmune or paraneoplastic etiology, HSV, syphilis, } \\
\text { HHV-6 }\end{array}$ \\
\hline $\begin{array}{l}\text { White matter T2/FLAIR hyperintensities } \\
\text { (without contrast enhancement) }^{\mathrm{a}}\end{array}$ & $\begin{array}{l}\text { Multiple sclerosis (classically causes periventricular T2/FLAIR hyperintensities, } \\
\text { i.e., "Dawson's fingers") } \\
\text { Other inflammatory/demyelinating conditions (NMO, ADEM, } \\
\text { neurosarcoidosis, Behçet's disease, Sjögren's syndrome) } \\
\text { Vascular pathologies (vasculitis, migraine, microvascular changes, } \\
\text { CAA-related inflammation, Susac's syndrome, CADASIL, postradiation } \\
\text { changes) } \\
\text { Arboviruses (classically causes T2/FLAIR hyperintensities of the basal ganglia } \\
\text { and deep nuclei) } \\
\text { Other viral infections (PML, HIV encephalopathy) } \\
\text { Primary neoplasms (glioma, gliomatosis cerebri, lymphomatosis cerebri, } \\
\text { intravascular lymphoma) } \\
\text { Toxic exposures (methotrexate, cytarabine, toluene, heroin, alcohol) } \\
\text { Leukodystrophies and mitochondrial diseases }\end{array}$ \\
\hline Cortical DWI “ribboning” & $\begin{array}{l}\text { Creutzfeldt-Jacob disease, hypoxic-ischemic brain injury, focal seizures, } \\
\text { mitochondrial disease }\end{array}$ \\
\hline $\begin{array}{l}\text { Microhemorrhages } \\
\text { (SWI susceptibility hypointensities) }\end{array}$ & $\begin{array}{l}\text { CAA, CAA-related inflammation, amyloid- } \beta \text {-related angiitis, CADASIL, } \\
\text { disseminated intravascular coagulation, H1N1 influenza, ITP, and TTP }\end{array}$ \\
\hline Intra-axial rim enhancement ${ }^{a}$ & $\begin{array}{l}\text { "MAGIC DR": metastasis, abscess, glioma, infarction, contusion, } \\
\text { demyelination (usually “open" ring), radiation necrosis }\end{array}$ \\
\hline Pachymeningeal enhancement $^{a}$ & $\begin{array}{l}\text { Infectious and inflammatory, granulomatous diseases (syphilis, tuberculosis, } \\
\text { fungal infections, neurosarcoidosis, granulomatosis with polyangiitis) } \\
\text { Other inflammatory conditions (IgG4-related disease, idiopathic hypertrophic } \\
\text { pachymeningitis, Tolosa-Hunt, rheumatoid arthritis) } \\
\text { Neoplasms (meningioma, lymphoma, metastasis, histiocytic disorders, } \\
\text { including Rosai-Dorfman disease) }\end{array}$ \\
\hline Leptomeningeal enhancement $^{\mathrm{a}}$ & $\begin{array}{l}\text { Intracranial hypotension, meningitis, leptomeningeal carcinomatosis, } \\
\text { neurosarcoidosis, amyloid- } \beta \text {-related angiitis, CAA-related inflammation }\end{array}$ \\
\hline Nerve root enhancement ${ }^{a}$ & $\begin{array}{l}\text { External compression, Guillain-Barré syndrome, Elsberg syndrome, } \\
\text { metastasis, neurofibroma, schwannoma, granulomatous disease, } \\
\text { Lyme disease, CMV, schistosomiasis }\end{array}$ \\
\hline
\end{tabular}

Abbreviations: ADEM, acute disseminated encephalomyelitis; CAA, cerebral amyloid angiopathy; CADASIL, cerebral autosomal dominant arteriopathy with subcortical infarcts and leukoencephalopathy; CMV, cytomegalovirus; HHV6, human herpesvirus 6; HIV, human immunodeficiency virus; HSV, herpes simplex virus; ITP, idiopathic thrombocytopenic purpura; NMO, neuromyelitis optica; PML, progressive multifocal leukoencephalopathy; TTP, thrombotic thrombocytopenic purpura.

${ }^{a}$ Contrast enhancement, which results from the breakdown of blood-brain barrier, is indicative of active inflammation.

It is important to recognize that often the only marker of CNS inflammation is the presence of autoantibodies or OCBs, and that even in the absence of elevated protein or pleocytosis, these findings may be signs of pathology. ${ }^{52}$ The classic example is MS; however, OCBs in the CSF are not unique to MS and are simply a marker of the intrathecal production of immunoglobulins. Importantly, whenever CSF is sent for OCB analysis, there should be a parallel investigation of serum with a report on the relative band patterns in the CSF and serum to confirm the presence of intrathecal oligoclonal immunoglobulin production. ${ }^{53}$ Quantitative IgG analysis (i.e., IgG index) is an informative complementary test but is not considered a substitute for qualitative IgG assessment (OCBs), which has higher sensitivity and specificity. In addition to CSF cell counts with differential, cellular responses can be evaluated by analysis of
T-cell subsets and their CD4/CD8 ratio. ${ }^{54}$ This is, however, of limited value, and the normal values are not standardized (-Table 8). As discussed earlier, many autoantibodies serve as biomarkers of disease mediated by T cells.

Electroencephalography is rarely specific but often very informative diagnostically in evaluating patients with altered level of consciousness or localizing pathologic regions within the brain. Occasionally, certain findings may be suggestive of specific disease processes (see - Table 6 for details). ${ }^{2,9}$ Additional investigations may be required to narrow down the differential diagnosis, establish a definitive diagnosis, or determine the extent of a systemic disease (-Table 6). Whole-body PET/CT may also be used to determine appropriate sites for diagnostic biopsy in patients with multisystem involvement. 
Table 6 Imaging and diagnostic studies for evaluation of patients with suspected autoimmune disorders of the nervous system

\begin{tabular}{|c|c|c|}
\hline Diagnostics & Finding & Potential diagnosis \\
\hline \multirow[t]{3}{*}{ CT/CTA head } & Vascular beading & Vasculitis \\
\hline & Venous engorgement & AVM, fistula, VST \\
\hline & Atrophy & Neurodegenerative process \\
\hline CT of the chest, abdomen/pelvis & Mass & Malignancy \\
\hline MRI spectroscopy & Lactate peak & Metabolic abnormalities \\
\hline \multicolumn{3}{|l|}{ Brain ${ }^{18}$ F-FDG-PET/CT } \\
\hline & $\begin{array}{l}\text { Medial temporal lobe hypermetabolism } \\
\text { (patterns of cerebral glucose metabolism } \\
\text { described in NMDAR and VGKC encephalitis) }\end{array}$ & Limbic encephalitis \\
\hline & Hypometabolic brain regions (not validated) ${ }^{48}$ & $\begin{array}{l}\text { Other forms of autoimmune } \\
\text { encephalitis }\end{array}$ \\
\hline Whole-body ${ }^{18}$ F-FDG-PET/CT & Areas of FDG avidity & Malignancy, inflammation \\
\hline \multirow[t]{4}{*}{ EEG } & Extreme delta brush & NMDAR encephalitis \\
\hline & PSWC & CJD \\
\hline & Periodic temporal discharges & HSV \\
\hline & Diffuse slowing with triphasics & Metabolic encephalopathy \\
\hline Mammogram & Breast lesion (cancer) & $\begin{array}{l}\text { Conditions associated with several } \\
\text { antineuronal antibodies, including } \\
\text { anti-amphiphysin }\end{array}$ \\
\hline Transvaginal US & Ovarian mass & NMDAR encephalitis \\
\hline Testicular US & Testicular mass (cancer) & $\begin{array}{l}\text { Brainstem, limbic encephalitis, } \\
\text { cerebellar degeneration }\end{array}$ \\
\hline \multirow[t]{3}{*}{$\begin{array}{l}\text { Dilated funduscopic examination } \\
\text { and fluorescein angiography }\end{array}$} & $\begin{array}{l}\text { Branch retinal artery occlusions with } \\
\text { hyperfluorescence of the vessel wall }\end{array}$ & Susac's syndrome \\
\hline & Uveitis & $\begin{array}{l}\text { Sarcoidosis, Behçet disease, other } \\
\text { rheumatologic conditions }\end{array}$ \\
\hline & $\begin{array}{l}\text { Vitreous opacities, sub-retinal pigment } \\
\text { epithelial infiltrates }\end{array}$ & $\begin{array}{l}\text { Intraocular-central nervous system } \\
\text { lymphoma }\end{array}$ \\
\hline Temporal artery biopsy & Granulomatous inflammation & Giant cell arteritis \\
\hline Labial salivary gland biopsy & Focal lymphocytic sialadenitis & Sjögren syndrome \\
\hline
\end{tabular}

Abbreviations: AVM, arteriovenous malformation; CAA, cerebral amyloid angiopathy; CJD, Creutzfeldt-Jakob disease; HSV, herpes simplex virus; ${ }^{18}$ F-FDG-PET/CT, fluorine-18-fluorodeoxyglucose positron emission tomography/computed tomography; PSWC, periodic sharp wave complexes; US, ultrasound; VST, venous sinus thrombosis.

Often the workup of neurologic disease yields only nonspecific markers of inflammation without providing a specific diagnosis, in which case stereotactic brain biopsy may be required to further narrow the pathologic process and guide treatment. When considering CNS biopsy, the potential diagnostic benefit must be weighed against the risk of permanent neurologic injury. With that said, in patients with rapidly progressive neurologic deterioration of uncertain etiology, often the value is sufficiently high and morbidity sufficiently low to justify the use of biopsy. ${ }^{55}$ In general, targets for biopsy should be in regions of active disease involvement on neuroimaging. When the area of active involvement is inaccessible, the potential diagnostic yield of biopsy drops considerably and the utility of such an intervention should be further considered. When feasible, brain and/or meningeal biopsy yields invaluable information regarding the nature of the inflammatory response, the underlying cellular/immune process, and the microstructural distribution of the inflammation, all of which can have significant impact on the choice of therapy. Demonstration of characteristic histopathological findings is the method of choice for making definitive diagnosis of vasculitis, sarcoidosis, IgG4RD, and neoplasm. ${ }^{29,40-42,56}$

\section{Treatment Options}

In the ICU setting, the clinical examination and diagnostic workup must be focused on identifying specific pathophysiologic processes that allow for early targeted treatment, rather than solely aimed at securing a specific diagnosis. The balance between diagnostic confidence, the risk of disease progression, and the risks of treatments will ultimately define individual patient care. No large randomized controlled trials have been performed in patients with neuroinflammatory conditions, 
Table 7 CSF studies consistent with inflammation of the CNS

\begin{tabular}{|l|l|}
\hline CSF study & Result \\
\hline Glucose & Normal \\
\hline Protein & Elevated \\
\hline WBCs & $5-100$ \\
\hline IgG index & $>0.66$ \\
\hline Oligoclonal bands & $\begin{array}{l}>1 \\
\text { (laboratory-dependent value) }\end{array}$ \\
\hline Paraneoplastic panel & Positive \\
\hline $\begin{array}{l}\text { New generation } \\
\text { sequencing of } \\
\text { microbial DNA }\end{array}$ & Negative \\
\hline Flow cytometry & Normal \\
\hline Cytology & Normal \\
\hline HSV1/HSV2 PCR & Negative \\
\hline VZV PCR and Ab & Negative \\
\hline B2 microglobulin & Normal \\
\hline IgH gene rearrangement & Absent \\
\hline
\end{tabular}

Abbreviations: CNS, central nervous system; CSF, cerebrospinal fluid; WBCs, white blood cells.

except for MS. The initial therapy often serves both as an initial treatment and a diagnostic test. It should be kept in mind that patients with autoimmune disorders might not respond to initial immunotherapeutic agent or could need intensive and prolonged therapies; conversely, patients with other disorders, such as primary CNS lymphoma, may respond to immunotherapy. - Table 1 lists categories of autoimmune pathophysiology and associated disorders as well as potential acute interventions. Glucocorticoids, intravenous immunoglobulin(IVIG), and plasma exchange (plasmapheresis) should be reserved for induction (management of active disease to induce remission), primarily because of their rapid onset and nonspecific effects on the immune system. ${ }^{1,57-60}$ Maintenance immunotherapy includes various agents that modulate immune response more specifically. ${ }^{1,59,61}$ The risk of these interventions is real and may significantly contribute to secondary sequelae such as opportunistic infections. It is important to realize that this is true for other widely accepted indications for these medications including immune suppression in organ transplantation.

The treatment of immunologic diseases of the brain is not limited to immunomodulation but includes the supportive management of associated secondary symptoms. The clinical course of patients with autoimmune neurologic disorders is frequently complicated by periods of both agitation and paroxysmal sympathetic hyperactivity, each of which may be superimposed on a backdrop of often-profound encephalopathy. ${ }^{62,63}$ There is little data available to guide clinicians about the most appropriate ways to manage these difficult and often refractory symptoms, which frequently lead to major morbidity and mortality for otherwise reversible disorders. Our recommendations for pharmacological interventions are based mainly on experiences with patients who have suffered traumatic brain injury, stroke, and subarachnoid hemorrhage. ${ }^{64-66}$ Overall, we advocate for nonpharmacologic measures, such as promoting the presence of family at the bedside, reinforcement of appropriate cues to promote a normal circadian rhythm, keeping familiar sights and sounds with personal pictures and music in the room, and other delirium precautions. In the event these environmental interventions are insufficient, pharmacological interventions are instituted. Our recommended treatment options are presented in - Table 9. The interventions are grouped into three different sections, which are at times difficult to separate clinically: paroxysmal sympathetic hyperactivity, agitation, and shivering control during aggressive temperature management. ${ }^{64-69}$

Finally, many of these disorders are paraneoplastic, occurring in the setting of neoplasia (malignant or benign tumors). These lesions are frequently small but need to be identified and treated rapidly to decrease the antigen load. ${ }^{2}$ Testing can often take weeks to occur, whereas neurologic deterioration can occur over hours. For example, surgical resection of an ovarian teratoma identified on imaging in a patient with a clear-cut clinical syndrome of anti-NMDA receptor encephalitis should not be delayed while awaiting the results of serology. Cases of paraneoplastic autoimmune neurologic disorders require multidisciplinary therapy plans developed by neurologists, oncologists, radiation therapists, and surgeons.

Table 8 Selected markers of adaptive immune response in CSF

\begin{tabular}{|l|l|}
\hline CSF constituents & Differential diagnosis \\
\hline $\begin{array}{l}\text { Oligoclonal bands }>1 \text { (number of bands for positive result is } \\
\text { defined by each laboratory; comparison with serum is } \\
\text { mandatory) }\end{array}$ & $\begin{array}{l}\text { Autoimmune diseases with intrathecal immunoglobulin } \\
\text { production (MS, ADEM, neurosarcoidosis, Behçet's disease, } \\
\text { SLE, Sjögren's syndrome, paraneoplastic or autoimmune } \\
\text { disorders caused by antineuronal antibodies) } \\
\text { CNS infections (neurosyphilis, neuroborreliosis, } \\
\text { HIV encephalitis) } \\
\text { Lymphoma }\end{array}$ \\
\hline $\begin{array}{l}\text { IgG index }=(\text { CSF IgG/CSF albumin)/(serum IgG/serum } \\
\text { albumin) }>0.66 \text { (laboratory-dependent value) }\end{array}$ & $\begin{array}{l}\text { Immunoglobulin targeting antigens within CNS } \\
\text { Autoantibodies }\end{array}$ \\
\hline
\end{tabular}

Abbreviations: ADEM, acute disseminated encephalomyelitis; CNS, central nervous system; CSF, cerebrospinal fluid; MS, multiple sclerosis; SLE, systemic lupus erythematosus. 
Table 9 Pharmacologic management of sympathetic hyperactivity, agitation, and shivering

\begin{tabular}{|c|c|c|c|c|c|}
\hline \multicolumn{2}{|c|}{ Sympathetic hyperactivity } & \multicolumn{2}{|l|}{ Agitation } & \multicolumn{2}{|l|}{ Shivering } \\
\hline Agent & Maximum dose & Agent & Maximum dose & Agent & Maximum dose \\
\hline Propranolol & $520 \mathrm{mg} / \mathrm{d}$ & Propranolol & $520 \mathrm{mg} / \mathrm{d}$ & Acetaminophen & $4 \mathrm{~g} / \mathrm{d}$ \\
\hline Clonidine & $1.2 \mathrm{mg} / \mathrm{d}$ & Pindolol & $100 \mathrm{mg} / \mathrm{d}$ & Buspirone & $90 \mathrm{mg} / \mathrm{d}$ \\
\hline Morphine & $20 \mathrm{mg} / \mathrm{d}$ & Dexmedetomidine & $1 \mathrm{mg} / \mathrm{kg} / \mathrm{h}$ & Magnesium & $1 \mathrm{~g} / \mathrm{h}$ \\
\hline Methadone & $40 \mathrm{mg} / \mathrm{d}$ & Benzodiazepines & NA & Meperidine & $400 \mathrm{mg} / \mathrm{d}$ \\
\hline Benzodiazepines & NA & Propofol & $83 \mu \mathrm{g} / \mathrm{kg} / \mathrm{min}$ & Fentanyl & $25 \mu \mathrm{g} / \mathrm{h}$ \\
\hline Gabapentin & $4,800 \mathrm{mg} / \mathrm{d}$ & Ketamine & $0.5 \mathrm{mg} / \mathrm{kg} / \mathrm{h}$ & Dantrolene & $2.5 \mathrm{mg} / \mathrm{kg}$ \\
\hline Dantrolene & $10 \mathrm{mg} / \mathrm{kg} / \mathrm{d}$ & Quetiapine & $300 \mathrm{mg} / \mathrm{d}$ & Clonidine & $1.2 \mathrm{mg} / \mathrm{d}$ \\
\hline Baclofen $(\mathrm{PO} / \mathrm{IT})$ & $80 \mathrm{mg} / \mathrm{d}$ & Olanzapine & $20 \mathrm{mg} / \mathrm{d}$ & Dexmedetomidine & $1 \mathrm{mg} / \mathrm{kg} / \mathrm{h}$ \\
\hline Bromocriptine & $40 \mathrm{mg} / \mathrm{d}$ & Ziprasidone & $80 \mathrm{mg} / \mathrm{d}$ & Propofol & $83 \mu \mathrm{g} / \mathrm{kg} / \mathrm{min}$ \\
\hline Chlorpromazine & $60 \mathrm{mg} / \mathrm{d}$ & Loxapine & $250 \mathrm{mg} / \mathrm{d}$ & Neuromuscular paralysis & $\mathrm{N} / \mathrm{A}$ \\
\hline \multirow[t]{12}{*}{ Propofol } & $83 \mu \mathrm{g} / \mathrm{kg} / \mathrm{min}$ & Haloperidol & $100 \mathrm{mg} / \mathrm{d}$ & & \\
\hline & & Clozapine & $750 \mathrm{mg} / \mathrm{d}$ & & \\
\hline & & Valproate & $2,250 \mathrm{mg} / \mathrm{d}$ & & \\
\hline & & Lamotrigine & $50 \mathrm{mg} / \mathrm{d}$ & & \\
\hline & & Phenobarbital & $240 \mathrm{mg} \times 1$ & & \\
\hline & & Carbamazepine & $800 \mathrm{mg} / \mathrm{d}$ & & \\
\hline & & Buspirone & $20 \mathrm{mg} / \mathrm{d}$ & & \\
\hline & & Amitriptyline & $75 \mathrm{mg} / \mathrm{d}$ & & \\
\hline & & Sertraline & $200 \mathrm{mg} / \mathrm{d}$ & & \\
\hline & & Lithium & $900 \mathrm{mg} / \mathrm{d}$ & & \\
\hline & & Amantadine & $400 \mathrm{mg} / \mathrm{d}$ & & \\
\hline & & Methylphenidate & $30 \mathrm{mg} / \mathrm{d}$ & & \\
\hline
\end{tabular}

Table 10 Suggested pretreatment screening studies and baseline evaluations before initiating immunosuppressive agents

\begin{tabular}{|c|c|}
\hline Infection screens & $\begin{array}{l}\text { Other diagnostic } \\
\text { studies }\end{array}$ \\
\hline $\begin{array}{l}\text { Hepatitis B screening } \\
\text { (HBsAg, anti-HBs, anti-HBc) }^{a}\end{array}$ & $\mathrm{CBC}^{\mathrm{a}}$ \\
\hline $\begin{array}{l}\text { Hepatitis C screening } \\
\text { (anti-HCV) }^{\mathrm{a}}\end{array}$ & $\mathrm{BUN} / \mathrm{Cr}^{\mathrm{a}}$ \\
\hline $\begin{array}{l}\text { HIV antibodies, }{ }^{\text {a }} \text { PCR; } \\
\text { T-cell CD4 count }\end{array}$ & $\mathrm{LFTs}^{\mathrm{a}}$ \\
\hline TB testing (PPD/IGRA) ${ }^{a}$ & hCG \\
\hline $\mathrm{JC}$ virus antibody index & $\begin{array}{l}\text { 25-hydroxycholecalciferol } \\
\text { (vitamin D) level }\end{array}$ \\
\hline $\begin{array}{l}\text { Strongyloides stercoralis, } \\
\text { serology }\end{array}$ & Bone densitometry \\
\hline \multirow{4}{*}{$\begin{array}{l}\text { Trypanosoma cruzi, } \\
\text { serology }\end{array}$} & TMPT genotype \\
\hline & CXR \\
\hline & Ophthalmologic evaluation \\
\hline & $\begin{array}{l}\text { Immunoglobulin levels } \\
(\lg M, \lg G, \lg A)\end{array}$ \\
\hline
\end{tabular}

Abbreviations: BUN, blood urea nitrogen; $\mathrm{CBC}$, complete blood cell count; $\mathrm{Cr}$, creatinine; CXR, chest X-ray; HCV, hepatitis C virus; IGRA, interferon-gamma release assay; LFTs, liver function tests; PPD, purified protein derivative; TMPT, 5-thiopurine-methyltransferase. ${ }^{\text {a }}$ Obtained from all patients.
Iatrogenic autoimmune complications of checkpoint inhibitors and CAR-T-cell therapy should always be managed in collaboration with the primary oncologist. Treatment of immune-related adverse events (irAEs) of checkpoint inhibitors includes interruption or permanent discontinuation of their use and may require corticosteroids and possibly even additional immunosuppressants, such as TNF $\alpha$ inhibitors and mycophenolate mofetil. ${ }^{70}$ As described earlier, the most prominent irAE of CAR-T-cell therapy is CRS, which is treated with the recombinant IL-6 receptor antagonist tocilizumab. The neurologic toxicities of CAR-T-cell therapy are generally also treated with corticosteroids, which have a superior bloodbrain barrier penetration to tocilizumab and may also act on pathologic immune pathways unrelated to CRS. ${ }^{25}$

\section{Treatment Risks}

Treatment with immunomodulatory agents incurs a significant risk for infection and other systemic side effects. The potential risks of adverse reactions can be minimized by screening evaluations, patient monitoring, and preventative measures. Baseline and screening laboratory testing that should be obtained before introducing immunomodulatory agents is listed in -Table 10, and preventative measures for infectious and noninfectious complications are outlined based on specific toxicities of individual medications in - Table 11. ${ }^{71}$ 
Table 11 Immunomodulatory therapies: dosing regimens, key risks and adverse effects, and suggested monitoring and prophylactic strategies

\begin{tabular}{|c|c|c|c|c|}
\hline $\begin{array}{l}\text { Immunotherapy } \\
\text { (mechanisms of action) }\end{array}$ & Dosing & Major risks & Prophylaxis & Monitoring parameters \\
\hline $\begin{array}{l}\text { Glucocorticoids } \\
\text { (genomic effects, nongenomic } \\
\text { effects: leukocyte adhesion and } \\
\text { cytokine modulation) }\end{array}$ & $\begin{array}{l}\text { Methylprednisolone } 1 \mathrm{~g} \text { IV QD } \\
\text { for 3-5 d } \\
\text { Prednisone start } 1 \mathrm{mg} / \mathrm{kg} / \mathrm{d} \\
\text { (60-80 mg QD) } \\
\text { Dexamethasone } 1-40 \mathrm{mg} \mathrm{Q6H}\end{array}$ & $\begin{array}{l}\text { Hyperglycemia, psychiatric } \\
\text { events, infections, adrenal } \\
\text { suppression, osteoporosis, } \\
\text { osteonecrosis, myopathy, } \\
\text { glaucoma, cataracts }\end{array}$ & $\begin{array}{l}\text { PPI, } \\
\text { Vitamin D }+ \text { calcium } \pm \\
\text { bisphosphonates and } \\
\text { alternatives } \\
\text { TMP/SMX/ atovaquone/ } \\
\text { dapsone }\end{array}$ & $\begin{array}{l}\text { Lipid profile } \\
\text { Ophthalmologic evaluation } \\
\text { Bone densitometry Q12 } \\
\text { months }\end{array}$ \\
\hline $\begin{array}{l}\text { IVIG } \\
\text { (autoantibodies, passive } \\
\text { immunization, complement } \\
\text { downregulation, cytokine } \\
\text { modulation) }\end{array}$ & $2 \mathrm{~g} / \mathrm{kg}$ over $3-5 \mathrm{~d}$ & $\begin{array}{l}\text { Hypersensitivity reactions, } \\
\text { thromboembolic events, } \\
\text { renal failure, aseptic } \\
\text { meningitis, hemolytic } \\
\text { anemia, neutropenia }\end{array}$ & $\begin{array}{l}\text { Acetaminophen } \\
\text { Diphenhydramine }\end{array}$ & $\begin{array}{l}\text { VS during infusion } \\
\text { BUN/Cr within } 10 \mathrm{~d} \text { after } \\
\text { initiation of IVIG treatment }\end{array}$ \\
\hline $\begin{array}{l}\text { Plasma exchange } \\
\text { (removal of pathogenic } \\
\text { antibodies from vascular } \\
\text { compartment, cytokine } \\
\text { modulation) }\end{array}$ & $\begin{array}{l}1-1.5 \text { plasma volumes, } \\
\text { typically } 5 \text { exchanges allowing } \\
\text { for vascular compartment } \\
\text { equilibration between } \\
\text { treatments (QOD) }\end{array}$ & $\begin{array}{l}\text { IV access complications; } \\
\text { hypocalcemia, hypotension, } \\
\text { arrhythmia, coagulopathy; } \\
\text { medication removal }\end{array}$ & $\begin{array}{l}\text { Calcium carbonate, fluids, } \\
\text { albumin, FFP }\end{array}$ & $\begin{array}{l}\text { CBC, electrolytes, Ig levels, } \\
\text { coagulation panel }\end{array}$ \\
\hline $\begin{array}{l}\text { Cyclophosphamide } \\
\text { (DNA alkylation, } \\
\text { Th1 suppressor, } \\
\text { and Th2 enhancer) }\end{array}$ & $\begin{array}{l}\text { Partners MS: } 800 \mathrm{mg} / \mathrm{m}^{2} \mathrm{IV} \\
\text { Q4 wk } \times 6 \\
\text { EULAR: } 15 \mathrm{mg} / \mathrm{kg} \text { IV Q2 } \mathrm{wk} \times 3 \\
\text { SLE NIH: } 0.5-1 \mathrm{~g} / \mathrm{m}^{2} \mathrm{Q} 4 \mathrm{wk} \times 6 \\
\text { EURO lupus: } 500 \mathrm{mg} \text { IV } \\
\text { Q2 wk } \times 6\end{array}$ & $\begin{array}{l}\text { Cytopenias, infections, } \\
\text { hemorrhagic cystitis, } \\
\text { malignancies (particularly } \\
\text { bladder cancer), gonadal } \\
\text { toxicity }\end{array}$ & $\begin{array}{l}\text { Aggressive IVF } \\
\text { Mesna } \\
\text { Antiemetics } \\
\text { TMP/SMX/atovaquone/dap- } \\
\text { sone } \\
\text { Fertility preservation } \\
\text { measures }\end{array}$ & $\begin{array}{l}\text { CBC w/ diff on days 7, 10, 14, } \\
27-28 \text { after IV, Q2 wk while } \\
\text { on PO } \\
\text { BUN/Cr Q2 wk } \\
\text { UA Q3-6 mo (continue after } \\
\text { discontinuation) }\end{array}$ \\
\hline $\begin{array}{l}\text { Anti-CD20 antibodies } \\
\text { (B-cell and plasmablast } \\
\text { depletion) }\end{array}$ & $\begin{array}{l}\text { Rituximab } 1,000 \mathrm{mg} \text { Q2 wk } \\
\times 2 \text { or } 375 \mathrm{mg} / \mathrm{m}^{2} \mathrm{Q} \text { week } \times 4 \\
\text { (usually } \mathrm{Q} 6 \mathrm{mo} \text { ) }\end{array}$ & $\begin{array}{l}\text { Hypersensitivity reactions, } \\
\text { hypogammaglobulinemia, } \\
\text { CVID, infections, PML }\end{array}$ & $\begin{array}{l}\text { HBV reactivation prophylaxis } \\
\text { Acetaminophen } \\
\text { Diphenhydramine } \\
\text { Methylprednisolone }\end{array}$ & $\begin{array}{l}\text { VS } \pm \text { telemetry during infusion } \\
\text { CBC w/ diff Q2-4 mo, CD19/20 } \\
\text { counts } \\
\text { lgG/lgM levels }\end{array}$ \\
\hline $\begin{array}{l}\text { TNF } \alpha \text { inhibitors } \\
\text { (inhibition of macrophage } \\
\text { activation via decrease in } \\
\text { TNFR } 1 / 2 \text { stimulation) }\end{array}$ & $\begin{array}{l}\text { Infliximab IV } 5 \mathrm{mg} / \mathrm{kg} \text { at } 0,2 \text {, } \\
6 \mathrm{wk} \text {, then Q4-8 wk } \\
\text { Adalimumab SC } 40 \mathrm{mg} \text { Q2 wk }\end{array}$ & $\begin{array}{l}\text { Hypersensitivity reactions, } \\
\text { hepatotoxicity, CNS and PNS } \\
\text { demyelination, including } \\
\text { optic neuritis, TB reactivation }\end{array}$ & $\begin{array}{l}\text { Treat latent TB } \\
\text { HBV reactivation prophylaxis } \\
\text { Consider TMP/SMX/atova- } \\
\text { quone/dapsone } \\
\text { Acetaminophen }\end{array}$ & $\begin{array}{l}\text { VS during infusion } \\
\text { CBC w/ diff } Q \geq 6 \text { mo } \\
\text { LFTs } Q \geq 6 \text { mo }\end{array}$ \\
\hline $\begin{array}{l}\text { Azathioprine } \\
\text { (DNA intercalation, inhibition } \\
\text { of purine synthesis) }\end{array}$ & $\begin{array}{l}\text { Start } 1 \mathrm{mg} / \mathrm{kg} / \mathrm{d} \text { ( } 50-100 \mathrm{mg} \\
\text { QD), then increase by } 50 \mathrm{mg} / \mathrm{wk} \\
\text { to } 2-3 \mathrm{mg} / \mathrm{kg} / \mathrm{d}\end{array}$ & $\begin{array}{l}\text { Hepatotoxicity, leukopenia } \\
\text { and other cytopenias, infec- } \\
\text { tions, GI toxicity (nausea, } \\
\text { diarrhea) }\end{array}$ & None & $\begin{array}{l}\text { TMPT genotype } \\
\text { pretreatment } \\
\text { Q1-2 wk while adjusting } \\
\text { dose, then Q4-12 wk: } \\
\text { CBC w/diff } \\
\text { LFTs }\end{array}$ \\
\hline $\begin{array}{l}\text { Methotrexate } \\
\text { (inhibition of thymidylate and } \\
\text { purine synthesis) }\end{array}$ & $\begin{array}{l}\text { PO: start } 7.5 \mathrm{mg} \mathrm{Q} \mathrm{wk} \text {, then } \\
\text { increase to } 15-25 \mathrm{mg} Q \mathrm{wk} \\
\text { SC: start } 7.5 \mathrm{mg} \mathrm{Q} \mathrm{wk} \text {, then } \\
\text { increase to } 10-25 \mathrm{mg} \mathrm{Q} \text { wk }\end{array}$ & $\begin{array}{l}\text { Nausea, diarrhea, mucositis, } \\
\text { cytopenias, hepatotoxicity, } \\
\text { (hypersensitivity } \\
\text { pneumonitis) }\end{array}$ & $\begin{array}{l}\text { Folic acid QD or folinic acid Q } \\
\text { wk } \\
\text { Sun protection }\end{array}$ & $\begin{array}{l}\text { CXR pretreatment } \\
\text { CBC w/diff Q2-4 wk for first } \\
12 \text { wk, then Q8-12 wk } \\
\text { LFTs Q8 wk }\end{array}$ \\
\hline $\begin{array}{l}\text { Mycophenolate mofetil } \\
\text { (inhibition of guanosine } \\
\text { synthesis) }\end{array}$ & $\begin{array}{l}\text { Start } 250 \text { or } 500 \mathrm{mg} \text { BID, then } \\
\text { increase by } 500 \mathrm{mg} / \mathrm{d} \text { every } \\
1-2 \text { wk to } 1,000-1,500 \mathrm{mg} \\
\text { BID }\end{array}$ & $\begin{array}{l}\text { Nausea, diarrhea, abdomen } \\
\text { pain, hepatotoxicity, cytope- } \\
\text { nias, hypertension, nephro- } \\
\text { toxicity, cough, dyspnea, } \\
\text { infections, headache, tremor }\end{array}$ & Sun protection & $\begin{array}{l}\text { Q1-2 wk for first } 12 \text { wk, then } \\
\text { Q6-8 wk: } \\
\text { CBC w/diff } \\
\text { BUN/Cr } \\
\text { LFTs }\end{array}$ \\
\hline $\begin{array}{l}\text { Eculizumab } \\
\text { (anti-C5 antibody) }\end{array}$ & $\begin{array}{l}\text { Eculizumab 400-1,200 mg IV } \\
\text { Q2 wk }\end{array}$ & $\begin{array}{l}\text { Hypersensitivity reactions, } \\
\text { hypertension, anemia }\end{array}$ & $\begin{array}{l}\text { Acetaminophen } \\
\text { Diphenhydramine }\end{array}$ & $\begin{array}{l}\mathrm{Cr}, \mathrm{CBC}, \mathrm{LDH} \text { up to } 12 \mathrm{wk} \\
\text { after last treatment }\end{array}$ \\
\hline $\begin{array}{l}\text { Tocilizumab } \\
\text { (anti-IL-6R antibody) }\end{array}$ & $\begin{array}{l}\text { Tocilizumab } 4-8 \mathrm{mg} / \mathrm{kg} \text { IV } \\
\text { Q4 wk or } 162 \mathrm{mg} \mathrm{SC} \mathrm{Q} \mathrm{wk}\end{array}$ & $\begin{array}{l}\text { Hypersensitivity reactions, GI } \\
\text { perforation, hepatotoxicity, } \\
\text { neutropenia, thrombocyto- } \\
\text { penia, TB reactivation }\end{array}$ & $\begin{array}{l}\text { Acetaminophen } \\
\text { Diphenhydramine }\end{array}$ & CBC, LFTs Q4 wk \\
\hline $\begin{array}{l}\text { Natalizumab } \\
\text { (anti- } \alpha 4 \text {-integrin antibody) }\end{array}$ & 300 mg IV Q4 wk & $\begin{array}{l}\text { PML, hypersensitivity } \\
\text { reactions }\end{array}$ & $\begin{array}{l}\text { Acetaminophen } \\
\text { Diphenhydramine }\end{array}$ & $\begin{array}{l}\text { VS during infusion } \\
\text { CBC, LFTs Q6 mo, anti-JCV } \\
\text { antibodies in seronegative } \\
\text { patients Q6 mo }\end{array}$ \\
\hline
\end{tabular}

Abbreviations: BUN, blood urea nitrogen; CBC, complete blood cell count; $\mathrm{Cr}$, creatinine; CVID, common variable immunodeficiency; CXR, chest X-ray; FFP, fresh frozen plasma; HBV, hepatitis B virus; IVF, intravenous fluids; IVIG, intravenous immunoglobulin; JCV, JC virus; LDH, lactate dehydrogenase; LFTs, liver function tests; PML, progressive multifocal leukoencephalopathy; PPI, proton pump inhibitor; TB, tuberculosis; Th1/Th2, T helper cell type 1/type2; TMP/SMX, trimethoprim/sulfamethoxazole; TMPT, 5-thiopurine-methyltransferase; TNFR1/2, tumor necrosis factor receptor 1/2; UA, urinalysis; VS, vital signs. 
Complications related to chronic immune suppression are due to opportunistic infections or noninfectious etiologies, including cancer; despite these, treatment is generally necessary as the autoimmune disease may lead to permanent neurologic injury. Vaccinations play a significant role in prevention against opportunistic infections in patients who are chronically immune suppressed, and vaccinations should be administered according to established guidelines (e.g., 2013 IDSA Clinical Practice Guideline for Vaccination of the Immunocompromised $\mathrm{Host}^{72}$ ). However, routine vaccinations against influenza, Streptococcus pneumoniae, and zoster are frequently avoided during the period of acute illness, as they may conceivably worsen immunologic disease.

Glucocorticoids and many immunomodulators increase the risk for Pneumocystis jiroveci pneumonia (PJP); this risk is more relevant in chronically immune suppressed patient, but antibiotic prophylaxis is frequently considered, in particular as patients started on steroids in the ICU often will require a prolonged taper.

- Table 11 lists available acute immunomodulatory regimens and associated prophylaxis. It is important to recognize that, while there are limited data guiding the use of these medications, the risk of withholding potentially efficacious treatment may outweigh risks associated with therapeutic agents for rapidly deteriorating patients.

Frequently, screening laboratory tests are positive, but immunologic treatment is still given; in these cases, additional antimicrobials, an infectious disease consultation, or additional discussions with the family regarding relative risks and benefits may be warranted. For example, JC virus (JCV) serologies are often positive prior to initiation of immunemodifying therapy, in which case the JCV antibody index may be useful to assess the relative risk of progressive multifocal leukoencephalopathy (PML) in the individual patient (JCV antibody index $>1.5$ indicates an increased risk for PML). ${ }^{73}$ The risk-benefit ratio of any immunosuppressive drug should be discussed with each patient and their family. Given their potential for significant toxicity, obtaining informed consent is required for certain immunosuppressants, such as cyclophosphamide, rituximab, and natalizumab.

Autoimmune neurologic disease is common in the younger people, and family planning should be addressed in each patient of reproductive age. Fertility preservation measures should be instituted in every patient in whom cyclophosphamide use is considered. Adjustment or discontinuation of immunosuppression should be considered before a planned pregnancy. Certain treatments are compatible with pregnancy, including glucocorticoids, IVIG, plasmapheresis, and azathioprine up to $2 \mathrm{mg} / \mathrm{kg} /$ day. ${ }^{74}$ TNF $\alpha$ inhibitors are considered reasonably safe within first and second trimester and during lactation. Methotrexate, mycophenolate mofetil, and cyclophosphamide must be discontinued before conception due to proven teratogenicity (pregnancy category D and $\mathrm{X}$ ). Most biologic agents have limited documentation on safe use in pregnancy and should be discontinued or replaced by other medication before conception.

Immunologic interventions may counteract the primary treatment goal in cases of iatrogenic autoimmune CNS disorders, where the initial treatment with CAR-T-cell therapy produces a robust tumor lysis response at the cost of CNS toxicity. In these cases, anti-IL-6 therapies such as tocilizumab may be employed first, but ultimately corticosteroids may be required to dampen and, as a result, potentially eliminate the therapeutic CAR-T-cell response. ${ }^{25}$

Finally, it should be recognized that immunologic interventions often affect the yield of future diagnostic studies. For example, treatment with IVIG will make the interpretation of future serologic studies particularly difficult, and treatment with glucocorticoids can significantly decrease the diagnostic yield of tissue biopsy of certain inflammatory and neoplastic lesions. For this reason, it is reasonable to collect extra serum and necessary tissue biopsies prior to the initiation of therapy.

\section{Conclusion}

Autoimmune neurologic disorders in the critical care unit often cause significant morbidity and mortality, and are associated with prolonged and expensive ICU stays. Fortunately, if treated rapidly, these are potentially reversible disorders. Focusing early interventions on appropriate mechanism-based therapy centered on suspected etiology with currently available immunomodulatory agents is essential to prevent irreversible neurologic injury and secure the best chance of a good outcome. Research aimed at expanding our understanding of the basic pathophysiology of these diseases will hopefully allow for more targeted interventions in years to come.

\section{References}

1 von Geldern G, McPharlin T, Becker K. Immune mediated diseases and immune modulation in the neurocritical care unit. Neurotherapeutics 2012;9(01):99-123

2 Dalmau J, Rosenfeld MR. Paraneoplastic syndromes of the CNS. Lancet Neurol 2008;7(04):327-340

3 Lancaster E, Dalmau J. Neuronal autoantigens-pathogenesis, associated disorders and antibody testing. Nat Rev Neurol 2012;8(07):380-390

4 Dalmau J, Tüzün E, Wu HY, et al. Paraneoplastic anti-N-methyl-Daspartate receptor encephalitis associated with ovarian teratoma. Ann Neurol 2007;61(01):25-36

5 Armangue T, Leypoldt F, Málaga I, et al. Herpes simplex virus encephalitis is a trigger of brain autoimmunity. Ann Neurol 2014; 75(02):317-323

6 Kroschinsky F, Stölzel F, von Bonin S, et al; Intensive Care in Hematological and Oncological Patients (iCHOP) Collaborative Group. New drugs, new toxicities: severe side effects of modern targeted and immunotherapy of cancer and their management. Crit Care 2017;21(01):89

7 Graus F, Titulaer MJ, Balu R, et al. A clinical approach to diagnosis of autoimmune encephalitis. Lancet Neurol 2016;15(04):391-404

8 Castillo P, Woodruff B, Caselli R, et al. Steroid-responsive encephalopathy associated with autoimmune thyroiditis. Arch Neurol 2006;63(02):197-202

9 Olmez I, Moses H, Sriram S, Kirshner H, Lagrange AH, Pawate S. Diagnostic and therapeutic aspects of Hashimoto's encephalopathy. J Neurol Sci 2013;331(1-2):67-71

10 Clementine RR, Lyman J, Zakem J, Mallepalli J, Lindsey S, Quinet R. Tumor necrosis factor-alpha antagonist-induced sarcoidosis. J Clin Rheumatol 2010;16(06):274-279 
11 Nyboe Andersen N, Pasternak B, Andersson M, Nielsen NM, Jess T. Risk of demyelinating diseases in the central nervous system in patients with inflammatory bowel disease treated with tumor necrosis factor inhibitors. JAMA Intern Med 2015;175(12):1990-1992

12 Stübgen JP. Tumor necrosis factor-alpha antagonists and neuropathy. Muscle Nerve 2008;37(03):281-292

13 Tristano AG. Neurological adverse events associated with antitumor necrosis factor $\alpha$ treatment. J Neurol 2010;257(09): 1421-1431

14 Moulis G, Sommet A, Lapeyre-Mestre M, Montastruc JL; Association Française des Centres Régionaux de PharmacoVigilance. Is the risk of tumour necrosis factor inhibitor-induced lupus or lupus-like syndrome the same with monoclonal antibodies and soluble receptor? A case/non-case study in a nationwide pharmacovigilance database. Rheumatology (Oxford) 2014;53(10): 1864-1871

15 Pardoll DM. The blockade of immune checkpoints in cancer immunotherapy. Nat Rev Cancer 2012;12(04):252-264

16 Sharma P, Allison JP. The future of immune checkpoint therapy. Science 2015;348(6230):56-61

17 Cuzzubbo S, Javeri F, Tissier M, et al. Neurological adverse events associated with immune checkpoint inhibitors: review of the literature. Eur J Cancer 2017;73:1-8

18 Bot I, Blank CU, Boogerd W, Brandsma D. Neurological immunerelated adverse events of ipilimumab. Pract Neurol 2013;13(04): 278-280

19 Joshi MN, Whitelaw BC, Palomar MT, Wu Y, Carroll PV. Immune checkpoint inhibitor-related hypophysitis and endocrine dysfunction: clinical review. Clin Endocrinol (Oxf) 2016;85(03): 331-339

20 Yshii LM, Gebauer CM, Pignolet B, et al. CTLA4 blockade elicits paraneoplastic neurological disease in a mouse model. Brain 2016:aww225

21 Williams TJ, Benavides DR, Patrice KA, et al. Association of autoimmune encephalitis with combined immune checkpoint inhibitor treatment for metastatic cancer. JAMA Neurol 2016;73 (08):928-933

22 Jena B, Dotti G, Cooper LJ. Redirecting T-cell specificity by introducing a tumor-specific chimeric antigen receptor. Blood 2010;116(07):1035-1044

23 Shank BR, Do B, Sevin A, Chen SE, Neelapu SS, Horowitz SB. Chimeric antigen receptor $\mathrm{T}$ cells in hematologic malignancies. Pharmacotherapy 2017;37(03):334-345

24 Bonifant CL, Jackson HJ, Brentjens RJ, Curran KJ. Toxicity and management in CAR T-cell therapy. Mol Ther Oncolytics 2016; 3:16011

25 Brudno JN, Kochenderfer JN. Toxicities of chimeric antigen receptor T cells: recognition and management. Blood 2016;127(26): 3321-3330

26 Morgan RA, Chinnasamy N, Abate-Daga D, et al. Cancer regression and neurological toxicity following anti-MAGE-A3 TCR gene therapy. J Immunother 2013;36(02):133-151

27 Tobin WO, Pittock SJ. Autoimmune neurology of the central nervous system. Continuum (Minneap Minn) 2017;23(3, Neurology of Systemic Disease):627-653

28 Cervera R, Juan M, Shoenfeld Y. Pathogenic mechanisms and clinical relevance of autoantibodies. In: Shoenfeld Y, Meroni PL, Gershwin ME, eds. Autoantibodies. 3rd ed. Oxford, UK: Elsevier B. V.; 2014

29 Agnihotri SP, Singhal T, Stern BJ, Cho TA. Neurosarcoidosis. Semin Neurol 2014;34(04):386-394

30 Biotti D, Deschamps R, Shotar E, et al. CLIPPERS: chronic lymphocytic inflammation with pontine perivascular enhancement responsive to steroids. Pract Neurol 2011;11(06):349-351

31 Wingerchuk DM, Banwell B, Bennett JL, et al; International Panel for NMO Diagnosis. International consensus diagnostic criteria for neuromyelitis optica spectrum disorders. Neurology 2015;85 (02):177-189
32 Reindl M, Jarius S, Rostasy K, Berger T. Myelin oligodendrocyte glycoprotein antibodies: how clinically useful are they? Curr Opin Neurol 2017;30(03):295-301

33 Fang B, McKeon A, Hinson SR, et al. Autoimmune glial fibrillary acidic protein astrocytopathy: a novel meningoencephalomyelitis. JAMA Neurol 2016;73(11):1297-1307

34 Shahrizaila N, Yuki N. Bickerstaff brainstem encephalitis and Fisher syndrome: anti-GQ1b antibody syndrome. J Neurol Neurosurg Psychiatry 2013;84(05):576-583

35 Shams'ili S, Grefkens J, de Leeuw B, et al. Paraneoplastic cerebellar degeneration associated with antineuronal antibodies: analysis of 50 patients. Brain 2003;126(Pt 6):1409-1418

36 Yu Z, Kryzer TJ, Griesmann GE, Kim K, Benarroch EE, Lennon VA. CRMP-5 neuronal autoantibody: marker of lung cancer and thymoma-related autoimmunity. Ann Neurol 2001;49(02):146-154

37 Lafitte C, Amoura Z, Cacoub P, et al. Neurological complications of primary Sjögren's syndrome. J Neurol 2001;248(07):577-584

38 Saip S, Akman-Demir G, Siva A. Neuro-Behçet syndrome. Handb Clin Neurol 2014;121:1703-1723

39 Tenembaum S, Chitnis T, Ness J, Hahn JS; International Pediatric MS Study Group. Acute disseminated encephalomyelitis. Neurology 2007;68(16, Suppl 2):S23-S36

40 Lu LX, Della-Torre E, Stone JH, Clark SW. IgG4-related hypertrophic pachymeningitis: clinical features, diagnostic criteria, and treatment. JAMA Neurol 2014;71(06):785-793

41 Bhattacharyya S, Berkowitz AL. Primary angiitis of the central nervous system: avoiding misdiagnosis and missed diagnosis of a rare disease. Pract Neurol 2016;16(03):195-200

42 Hajj-Ali RA, Singhal AB, Benseler S, Molloy E, Calabrese LH. Primary angiitis of the CNS. Lancet Neurol 2011;10(06):561-572

43 Bhattacharyya S, Helfgott SM. Neurologic complications of systemic lupus erythematosus, Sjögren syndrome, and rheumatoid arthritis. Semin Neurol 2014;34(04):425-436

44 The Antiphospholipid Antibodies in Stroke Study Group. Clinical and laboratory findings in patients with antiphospholipid antibodies and cerebral ischemia. Stroke 1990;21(09):1268-1273

45 Eng JA, Frosch MP, Choi K, Rebeck GW, Greenberg SM. Clinical manifestations of cerebral amyloid angiopathy-related inflammation. Ann Neurol 2004;55(02):250-256

46 Hardy TA, Chataway J. Tumefactive demyelination: an approach to diagnosis and management. J Neurol Neurosurg Psychiatry 2013; 84(09):1047-1053

47 Leypoldt F, Buchert R, Kleiter I, et al. Fluorodeoxyglucose positron emission tomography in anti-N-methyl-D-aspartate receptor encephalitis: distinct pattern of disease. J Neurol Neurosurg Psychiatry 2012;83(07):681-686

48 Probasco JC, Solnes L, Nalluri A, et al. Abnormal brain metabolism on FDG-PET/CT is a common early finding in autoimmune encephalitis. Neurol Neuroimmunol Neuroinflamm 2017;4(04):e352

49 Graus F, Dalmau J. Role of (18)F-FDG-PET imaging in the diagnosis of autoimmune encephalitis - Authors' reply. Lancet Neurol 2016; 15(10):1010

50 Chow E, Troy SB. The differential diagnosis of hypoglycorrhachia in adult patients. Am J Med Sci 2014;348(03):186-190

51 Motuzova Y, Di Sapio A, Capobianco M, et al. Peculiar cytological cerebrospinal fluid pattern in a case of encephalomyelitis during anti-tumor necrosis factor- $\alpha$ therapy. Neurol Ther 2015;4(01): $53-60$

52 McKeon A, Pittock SJ, Lennon VA. CSF complements serum for evaluating paraneoplastic antibodies and NMO-IgG. Neurology 2011;76(12):1108-1110

53 Freedman MS, Thompson EJ, Deisenhammer F, et al. Recommended standard of cerebrospinal fluid analysis in the diagnosis of multiple sclerosis: a consensus statement. Arch Neurol 2005; 62(06):865-870

54 de Graaf MT, de Jongste AH, Kraan J, Boonstra JG, Sillevis Smitt PA, Gratama JW. Flow cytometric characterization of cerebrospinal fluid cells. Cytometry B Clin Cytom 2011;80(05):271-281 
55 Burns JD, Cadigan RO, Russell JA. Evaluation of brain biopsy in the diagnosis of severe neurologic disease of unknown etiology. Clin Neurol Neurosurg 2009;111(03):235-239

56 Scolding NJ, Joseph F, Kirby PA, et al. Abeta-related angiitis: primary angiitis of the central nervous system associated with cerebral amyloid angiopathy. Brain 2005;128(Pt 3):500-515

57 Gwathmey K, Balogun RA, Burns T. Neurologic indications for therapeutic plasma exchange: 2013 update. J Clin Apher 2014;29 (04):211-219

58 Linker RA, Gold R. Use of intravenous immunoglobulin and plasma exchange in neurological disease. Curr Opin Neurol 2008;21(03):358-365

59 McDaneld LM, Fields JD, Bourdette DN, Bhardwaj A. Immunomodulatory therapies in neurologic critical care. Neurocrit Care 2010;12(01):132-143

60 Schwartz J, Winters JL, Padmanabhan A, et al. Guidelines on the use of therapeutic apheresis in clinical practice-evidence-based approach from the Writing Committee of the American Society for Apheresis: the sixth special issue. J Clin Apher 2013;28(03):145-284

61 Hauser SL, Waubant E, Arnold DL, et al; HERMES Trial Group. B-cell depletion with rituximab in relapsing-remitting multiple sclerosis. N Engl J Med 2008;358(07):676-688

62 Rabinstein AA, Benarroch EE. Treatment of paroxysmal sympathetic hyperactivity. Curr Treat Options Neurol 2008;10(02):151-157

63 Baguley IJ. Autonomic complications following central nervous system injury. Semin Neurol 2008;28(05):716-725

64 Chew E, Zafonte RD. Pharmacological management of neurobehavioral disorders following traumatic brain injury-a state-ofthe-art review. J Rehabil Res Dev 2009;46(06):851-879

65 Bhatnagar S, Iaccarino MA, Zafonte R. Pharmacotherapy in rehabilitation of post-acute traumatic brain injury. Brain Res 2016; 1640(Pt A):164-179

66 Choi HA, Badjatia N, Mayer SA. Hypothermia for acute brain injury-mechanisms and practical aspects. Nat Rev Neurol 2012; 8(04):214-222

67 Tsaousi GG, Lamperti M, Bilotta F. Role of dexmedetomidine for sedation in neurocritical care patients: a qualitative systematic review and meta-analysis of current evidence. Clin Neuropharmacol 2016;39(03):144-151
68 Duby JJ, Berry AJ, Ghayyem P, Wilson MD, Cocanour CS. Alcohol withdrawal syndrome in critically ill patients: protocolized versus nonprotocolized management. J Trauma Acute Care Surg 2014;77(06):938-943

69 Weant KA, Martin JE, Humphries RL, Cook AM. Pharmacologic options for reducing the shivering response to therapeutic hypothermia. Pharmacotherapy 2010;30(08):830-841

70 Marrone KA, Ying W, Naidoo J. Immune-related adverse events from immune checkpoint inhibitors. Clin Pharmacol Ther 2016; 100(03):242-251

71 Vodopivec I, Miloslavsky EM, Kotton CN, Cho TA. A neurologist's guide to safe use of immunomodulatory therapies. Semin Neurol 2014;34(04):467-478

72 Rubin LG, Levin MJ, Ljungman P, et al; Infectious Diseases Society of America. 2013 IDSA clinical practice guideline for vaccination of the immunocompromised host. Clin Infect Dis 2014;58(03): e44-e100

73 Plavina T, Subramanyam M, Bloomgren G, et al. Anti-JC virus antibody levels in serum or plasma further define risk of natalizumab-associated progressive multifocal leukoencephalopathy. Ann Neurol 2014;76(06):802-812

74 Götestam Skorpen C, Hoeltzenbein M, Tincani A, et al. The EULAR points to consider for use of antirheumatic drugs before pregnancy, and during pregnancy and lactation. Ann Rheum Dis 2016; 75(05):795-810

75 Chung JH, Van Stavern GP, Frohman LP, Turbin RE. Adalimumabassociated optic neuritis. J Neurol Sci 2006;244(1-2):133-136

76 Beauchemin P, Carruthers R. MS arising during Tocilizumab therapy for rheumatoid arthritis. Mult Scler 2016;22(02):254-256

77 Shirai T, Sano T, Kamijo F, et al. Acetylcholine receptor binding antibody-associated myasthenia gravis and rhabdomyolysis induced by nivolumab in a patient with melanoma. Jpn J Clin Oncol 2016;46(01):86-88

78 Wick W, Hertenstein A, Platten M. Neurological sequelae of cancer immunotherapies and targeted therapies. Lancet Oncol 2016;17(12):e529-e541

79 Tchapyjnikov D, Borst AJ. Immune-related neurological symptoms in an adolescent patient receiving the checkpoint inhibitor nivolumab. J Immunother 2017;40(07):286-288 